\title{
Determinanty nadmiernego zadłużania się polskich gospodarstw domowych
}

\author{
AGNIESZKA WIŚNIEWSKA \\ mgr, Uniwersytet Szczeciński, Wydział Zarządzania i Ekonomiki Usług \\ e-mail: agnieszka.wisniewska@wzieu.pl
}

SŁoWA KLUCzowe gospodarstwo domowe, zadłużenie, decyzje finansowe, kredyt bankowy, program „Rodzina 500+”

Decyzje finansowe, podejmowane przez gospodarstwa domowe mają istotny wpływ na charakter i kształt współczesnych gospodarek państwowych. Dochody, wydatki, a także oszczędności i inwestycje to tylko niektóre z elementów, poprzez które gospodarstwa domowe wpływają na stymulację gospodarki. Rośnie świadomość konsumencka oraz poziom edukacji finansowej, jednak w dalszym ciągu wśród polskich gospodarstw domowych występuje zjawisko nadmiernego zadłużania się. Cel - analiza należności wobec banków i instytucji finansowych z tytułu zaciągniętych kredytów i pożyczek. Ponadto zwrócono uwagę na związek wprowadzonego w 2016 roku programu „Rodzina $500+$ " z poziomem zobowiązań, a także cele i skalę zadłużenia. W artykule wskazano na przyczyny nadmiernego zadłużania się polskich gospodarstw domowych w ostatnich latach.

Metodyka badania - analiza literatury, statystyczna analiza danych wtórnych.

Wynik - nadmierne zadłużanie się gospodarstw domowych jako problem społeczny i ekonomiczny. Z jednej strony wskazuje się na dużą dostępność wszelkiego rodzaju produktów kredytowych. Z drugiej strony, konsumpcyjny styl życia i brak dostatecznej wiedzy ekonomicznej oraz finansowej pociągają za sobą zagrożenie spiralą zadłużenia.

Wartość - wskazanie związku między wprowadzeniem programu „Rodzina 500+” a oszczędnościami i zadłużeniem. Zidentyfikowano czynniki powodujące nadmierne zadłużanie się w postaci autorskiej klasyfikacji.

\section{Determinants of excessive indebtedness of Polish households}

KEYWORDS: household, debt, financial decisions, bank credit, program "Family 500+"

Financial decisions made by households have a significant impact on the nature and shape of modern national economies. Income, expenses, as well as savings and investments are just some of the elements through which households influence economic stimulation. Consumer awareness and the level of education grow but still households are heavily debt.

Purpose - the purpose of this article is to analyze liabilities to banks or financial institutions for loans and borrowings. In addition, the author paid attention to the connection of the program "Family $500+$ " introduced in 2016 with the level of financial commitments of households as well as the objectives and the scale of the their debt. The article shows the causes of over-indebtedness of Polish households over the last year.

Methodology - literature analysis, statistical analysis of secondary data. 
Findings - excessive indebtedness of the households as a social and economic problem. On the one hand, it indicates the high availability of all types of credit products. On the other hand, consumer lifestyle and the lack of sufficient economic and financial knowledge entail a risk of debt spiral.

Value - the indication of connection between the introduction of the program "Family 500+" and savings and debt. The author identifies the factors with cause excessive indebtedness and according to the author's own classification of the factors.

\section{Wprowadzenie}

W każdej rozwiniętej gospodarce, gospodarstwa domowe odgrywają bardzo ważną rolę na rynku finansowym głównie dzięki gromadzeniu oszczędności oraz zaciąganiu zobowiązań. Duża aktywność na rynku finansowym powoduje zwiększenie poziomu zadowolenia z życia poprzez np. zyski z odsetek od depozytów zwiększają dochód rozporządzalny; co może być przeznaczone na zaspokojenie kolejnej z nieograniczonej liczby potrzeb konsumpcyjnych. Dzięki kredytom i innym finansowym instrumentom dłużnym możliwe jest nabycie dóbr, których zakup w innych warunkach byłby niemożliwy lub wiązałby się ze zgromadzeniem bardzo dużych środków np. zakup mieszkania czy samochodu. Z drugiej zaś strony, aktywność ta może prowadzić do powstania spirali zadłużenia - gospodarstwa domowe nie biorą pod uwagę czynników losowych czy zmian koniunkturalnych (np. utrata pracy, nagła choroba, pogłębiająca się recesja), przez co wielokrotnie swoje zobowiązania finansowe muszą regulować za pomocą zaciągania kolejnych zobowiązań. Należy zwrócić także uwagę, że obecność gospodarstw domowych na rynku finansowym w dużej mierze jest uwarunkowana bieżącą sytuacją materialną, statusem społecznym czy też składem osobowym danego gospodarstwa. Konsumenci, dążąc do jak najpełniejszego zaspokojenia swoich potrzeb, wykorzystują instrumenty rynku finansowego do alokacji konsumpcji w czasie.

W ostatnich latach odnotowuje się wzrost zadłużenia polskich gospodarstw domowych z tytułu zaciągniętych zobowiązań. Celem artykułu jest analiza należności wobec banków i instytucji finansowych z tytułu zaciągniętych kredytów i pożyczek. Zwrócono ponadto uwagę na związek wprowadzonego w 2016 roku programu „Rodzina 500+” z poziomem zobowiązań, a także cele i skalę zadłużenia. W artykule wskazano na przyczyny nadmiernego zadłużania się polskich gospodarstw domowych w ostatnich latach.

\section{Gospodarstwo domowe, finanse osobiste, decyzje finansowe - ujęcie teoretyczne}

Gospodarstwo domowe jest wielokrotnie utożsamiane z pojęciami takimi, jak rodzina czy gospodarstwo konsumenckie lub gospodarstwo rodzinne. Należy także wskazać, że gospodarstwo domowe jest najstarszą na świecie instytucją ekonomiczną. Ze starożytnej Grecji pochodzą pierwsze ślady literatury ekonomicznej, dotyczącej zasad racjonalnego gospodarowania zasobami ludzkimi i majątkowymi, czyli zarządzania gospodarstwem domowym. Współcześnie, w teorii ekonomii, gospodarstwo domowe wymienia się jako podmiot gospodarowania, obok przedsiębiorstw i gospodarki narodowej. Istnieje wiele definicji gospodarstwa domowego, a ich 
adekwatność zależy od wybranego kryterium. Gospodarstwem domowym, według Samulesona, nazywa się podstawowy podmiot gospodarczy, którego najważniejsza funkcja to zgłaszanie popytu na rynku dóbr i usług konsumpcyjnych (Samuelson, Nordhaus, 1985, s. 564-565). Pałaszewska-Reindl i Michna definiują gospodarstwo domowe jako mikrojednostkę gospodarującą, która tworzy dochód, a następnie dokonuje jego podziału na różnego rodzaju cele. Ponadto produkuje dobra, świadczy usługi oraz gromadzi zapasy (Pałaszewska-Reindl, Michna, 1986, s. 34). Na potrzeby niniejszego artykułu przyjmuje się definicję zaproponowaną przez Światowy, wskazującą, że gospodarstwo domowe to podmiot gospodarujący, którego działalność oparta jest na własnych środkach materialnych oraz sile roboczej członków tego gospodarstwa (Światowy, 1994, s. 139).

Jak wskazano, gospodarstwo jest podmiotem gospodarującym, a więc dokonującym podziału swoich dochodów w celu realizacji określonych zadań konsumpcyjnych. Gospodarowanie ściśle związane jest z finansami osobistymi czy też finansami gospodarstw domowych. W odniesieniu do finansów gospodarstw domowych, w literaturze światowej występuje wiele definicji. Według Campbella, istota finansów gospodarstw domowych polega na realizacji celów gospodarstw domowych przy wykorzystaniu instrumentów finansowych (Campbell, 2006, s. 1553-1604). Polscy naukowy również podjęli próbę zdefiniowania pojęcia finansów gospodarstw domowych. Na wyróżnienie zasługuje definicja zaproponowana przez Jajugę (2007), Waliszewskiego (2011) czy Rytelewską (2008). Spośród wszystkich dostępnych ujęć, najbardziej właściwe wydaje się to, zaproponowane przez Świecką, która uważa, że finanse gospodarstw domowych to subdyscyplina nauk o finansach, zajmująca się pozyskiwaniem, gromadzeniem oraz wydatkowaniem środków pieniężnych. Dodatkowo, autorka wskazuje, że głównym nurtem zainteresowania tej części ekonomii jest obieg (ruch) pieniądza między gospodarstwami domowymi a innymi podmiotami, w tym gospodarką państwa, przedsiębiorstwami a także innymi gospodarstwami domowymi (Świecka, 2009, s. 64).

Gospodarstwa domowe, w zakresie finansów osobistych, podejmują wiele decyzji finansowych. Podejmowania decyzji nie można traktować jako jednostkowy moment wyboru, ale jako proces składający się z wielu etapów i przebiegający w określonym czasie. Źródła literaturowe nie określają jednoznacznie zasad czy procedur, jak postępować w przypadku danego problemu decyzyjnego. Spotyka się wiele różnych ujęć określających długość procesów decyzyjnych. Samuelson i Marks (1998, s. 28), wskazują na sześcioetapowy proces decyzyjny (zdefiniowanie problemu, określenie celu, zbadanie wariantów wyboru, przewidzenie konsekwencji, wybór optymalnego wariantu, doskonalenie analizy wrażliwości). Drucker (1994, s. 376-394), proces decyzyjny ujmuje w pięciu etapach, zaś Kozielecki (1986, s. 290), wymienia zaledwie trzy, podstawowe elementy procesu decyzyjnego: proces przewidywania, proces wartościowania oraz proces wyboru.

Proces decyzyjny gospodarstw domowych każdorazowo przebiega zgodnie z etapami podejmowania decyzji. Niejednokrotnie decyzje podejmowane są w sposób spontaniczny, a poszczególne etapy nie są zauważane - dzieją się automatycznie. Podobnie jest w momencie podejmowania decyzji finansowych, szczególnie w przypadku, gdy gospodarstwo domowe decyduje o swoich finansach bez dokonania dogłębnej analizy. Wśród decyzji finansowych, jakie podejmowane są przez gospodarstwa domowe wyróżnia się decyzje związane z konsumpcją 
i oszczędzaniem. Ponadto można wskazać decyzje inwestycyjne, kredytowe oraz te związane z zarządzaniem ryzykiem. Klasyfikację decyzji finansowych przedstawiono w tabeli 1.

Tabela 1. Decyzje finansowe gospodarstw domowych

\begin{tabular}{|l|l|}
\hline \multicolumn{1}{|c|}{ Decyzje konsumpcyjne } & \multicolumn{1}{|c|}{$\begin{array}{c}\text { Jaką część osiągniętego dochodu należy przeznaczyć na bieżącą konsumpcję } \\
\text { - spożycie? }\end{array}$} \\
\hline Decyzje inwestycyjne & $\begin{array}{l}\text { Mając zaoszczędzoną część dochodu - w jaki sposób należy zainwestować } \\
\text { zgromadzone pieniądze? }\end{array}$ \\
\hline Decyzje oszczędnościowe & Jaką część dochodu należy zaoszczędzić? \\
\hline Decyzje kredytowe & $\begin{array}{l}\text { W jaki sposób oraz w jakim czasie gospodarstwa domowe powinny zdecydować } \\
\text { się na użytkowanie pieniędzy innych podmiotów (ludzi, przedsiębiorstw, banków), } \\
\text { w formie kredytów i pożyczek, aby móc zrealizować zaplanowane wcześniej lub } \\
\text { powstałe wskutek zdarzenia losowego plany inwestycyjne lub konsumpcyjne? }\end{array}$ \\
\hline $\begin{array}{l}\text { Decyzje związane } \\
\text { z zarządzaniem ryzykiem }\end{array}$ & $\begin{array}{l}\text { W jaki sposób i na jakich zasadach gospodarstwa domowe powinny dokonywać } \\
\text { redukcji niepewności finansowej, a kiedy powinny zdecydować się na zwiększanie } \\
\text { tego ryzyka? }\end{array}$ \\
\hline
\end{tabular}

Źródło: opracowanie własne na podstawie Świecka, Musiał (2014), s. 91.

Jak wskazano, wymienia się pięć głównych typów decyzji finansowych, jakie podejmowane są w zakresie finansów osobistych. Na szczególną uwagę zasługują decyzje dotyczące zaciągania zobowiązań (decyzje kredytowe), które determinują procent dochodu jaki może zostać wydatkowany na cele konsumpcyjne. Decyzje związane z zadłużeniem niejednokrotnie wpływają także na poziom oszczędności lub ich całkowity brak.

\section{Zadłużenie gospodarstw domowych}

Według danych prezentowanych przez Narodowy Bank Polski, zobowiązania finansowe w drugim kwartale 2016 roku (do końca czerwca), wyniosły łącznie 679,5 mld zł (czyli o 1,7\% wyższe w porównaniu z poprzednim kwartałem). Dodatkowo na uwagę zasługuje to, że zobowiązanie gospodarstw domowych były wyższe aż o 3,9\% w stosunku do analogicznego okresu w roku ubiegłym. Raport NBP wskazuje również na to, że stan zobowiązań osobistych zwiększył się o 11,6 mld zł w drugim kwartale, z czego niespełna połowa - 5,11 mld zł to zobowiązania nowo podjęte. Na rysunku 1 przestawiono stan zobowiązań gospodarstw domowych.

Należności gospodarstw domowych wobec monetarnych instytucji finansowych w roku 2016 zdecydowanie przewyższają należności w analogicznych miesiącach roku poprzedniego. Największa różnica wystąpiła w miesiącu kwietniu (34,5 mln zł), zaś najmniejsza w styczniu (23,4 mln zł). Zarówno w 2015, jak i w 2016 roku regularnie, z miesiąca na miesiąc, zwiększają swoje zadłużenie. Dodatkowo suma wartości przyrostów zaciągniętych zobowiązań w relacji miesiąc do miesiąca, w roku 2016 jest wyższa niż w 2015 roku (mimo że 2016 r. nie został jeszcze zakończony). Gospodarstwa domowe swoje zobowiązania zaciągają głównie w celu finansowania konsumpcji, ale także w celu zakupu nieruchomości. W drugim kwartale 2016 roku, transakcje przeprowadzone w formie kredytów i pożyczek konsumpcyjnych, stanowiły ponad 44,6\% wartości wszystkich transakcji. Przy tym wartość ta była najwyższa od 2010 roku (www.nbp.pl). 
Rysunek 1. Należności monetarne instytucji finansowych od gospodarstw domowych - stany w mln zł (ujęcie miesięczne)

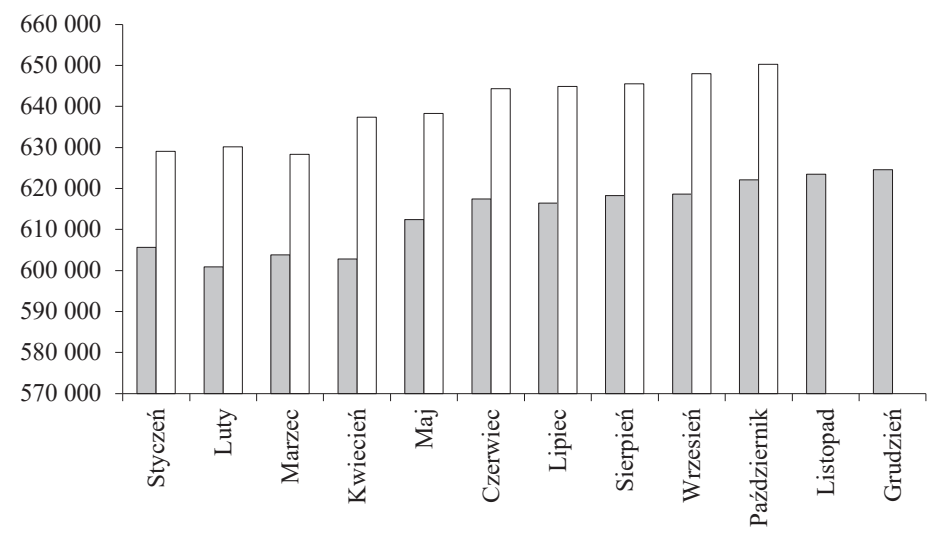

$$
\square 2015 \quad \square 2016
$$

Źródło: opracowanie własne na podstawie danych NBP (www.nbp.pl).

Sytuację kredytową gospodarstw domowych, pod względem zaciągniętych zobowiązań, należy także rozpatrywać w ujęciu rocznym. Jak widać na rysunku 2, właściwie od 2008 roku wartość należności wobec monetarnych instytucji finansowych od gospodarstw domowych stale rośnie. Największy przyrost wartości odnotowano w 2009 roku względem roku poprzedniego, zaś najmniejszy w 2013 roku w stosunku do 2012 roku (badano okresy od stycznia 2008 do grudnia 2015).

Rysunek 2. Wartość należności monetarnych instytucji finansowych od gospodarstw domowych - stany w mln zł (ujęcie roczne)

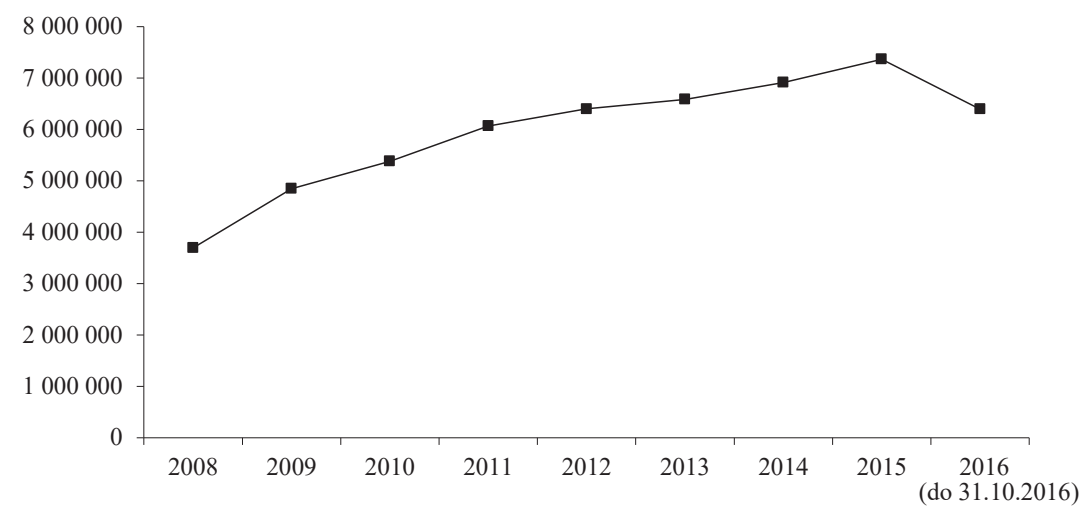

Źródło: opracowanie własne na podstawie danych NBP. 
Narodowy Bank Polski, w opracowaniu na temat sytuacji finansowej gospodarstw domowych, wskazuje, że od połowy 2015 roku wartość transakcji na kredytach konsumpcyjnych przewyższa wartość transakcji na kredytach mieszkaniowych (za wyjątkiem pierwszego kwartału 2016 r.). W kredytach i pożyczkach zaciąganych przez gospodarstwa domowe przeważają te na okres dłuższy niż rok - są to długoterminowe zobowiązania wobec sektora bankowego i w ujęciu rocznym wzrosły o 4,3\%. Kredyty i pożyczki krótkoterminowe (czyli takie, których czas trwania nie przewyższa jednego roku), w drugim kwartale 2016 roku były na poziomie zbliżonym do analogicznego okresu w roku poprzednim. Obserwuje się również ciągły - systematyczny wzrost zainteresowania kredytami zaciąganymi przez gospodarstwa domowe, które mają wydłużony okres spłaty.

Odnosząc się do czasu trwania zobowiązań gospodarstw domowych, należy zwrócić także uwagę na wysokość oszczędności. W roku 2011, liczba gospodarstw domowych, które wykazywały zobowiązania o wartości przekraczającej roczne dochody była większa od liczby gospodarstw domowych, które zgromadziły oszczędności w kwocie przekraczającej roczne dochody (rys. 3).

Rysunek 3. Wysokość oszczędności i zobowiązań gospodarstw domowych w przekrojach czasowych (\%)

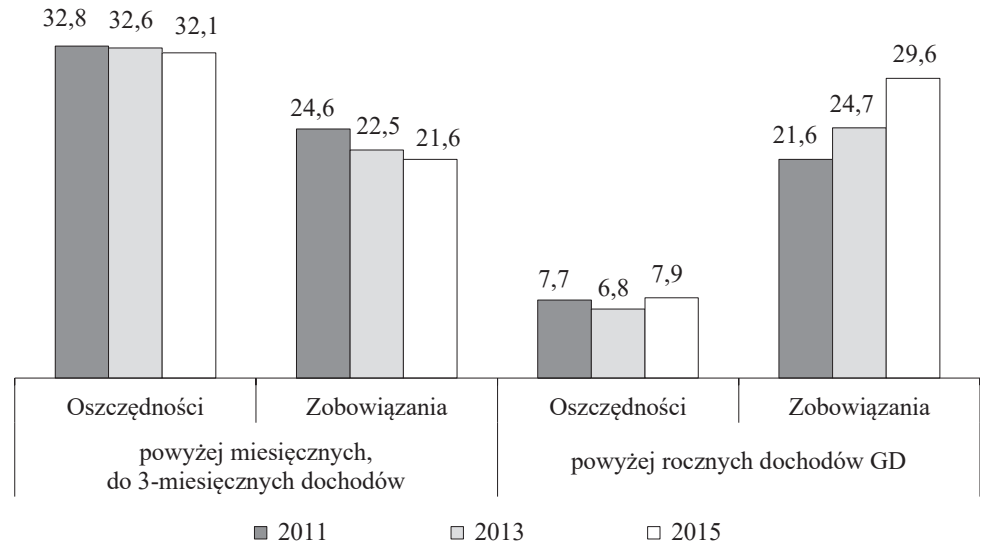

Źródło: opracowanie własne na postawie danych Diagnozy Społecznej (2015).

Z roku na rok poziom oszczędności, których wartość jest wyższa niż miesięczny dochód, ale niższa niż równowartość 3-miesięczych dochodów, stopniowo maleje. Podobna zależność jest odzwierciedlona w przypadku zobowiązań - wysokość zobowiązań o równowartości przewyższającej miesięczny dochód, ale nieprzekraczającej 3-miesięcznych dochodów z roku na rok ulega zmniejszeniu. Dodatkowo ciekawym zjawiskiem jest to, że gospodarstwa domowe charakteryzują się oszczędnościami w wysokości powyżej równowartości miesięcznych dochodów a poniżej 3-miesięcznych, aniżeli zobowiązań o tych samych wartościach. Sytuacja ta zmienia się jednak diametralnie, jeśli analizie zostaną poddane oszczędności i zobowiązania, których równowartość przewyższa roczne dochody gospodarstw domowych. Oszczędności utrzymują się na względnie stałym, podobnym poziomie - przeciętnie 7,5\% gospodarstw domowych ma 
oszczędności wyższe niż ich roczne dochody (najmniejszy poziom w 2013 - 6,8\%, zaś największy w 2015 - 7,9\%). Zobowiązania gospodarstw domowych, przekraczające ich roczne dochody, stale zwiększają się. Przyjmując dane prezentowane w Komunikacie Prezesa GUS, określające przeciętne wynagrodzenie w trzecim kwartale 2016 roku, które wyniosło 4055, 04 zł oraz odnosząc wyniki badania z 2015 roku, stwierdzić można, że średnio 25,3\% gospodarstw domowych ma zadłużenie sięgające poziomu powyżej 48 660,48 zł. W ciągu dwóch lat (2013-2015), wielkość zobowiązań powiększyła się o 4,9 p.p. (www.stat.gov.pl).

Jak wskazano, w każdym z analizowanych miesięcy 2016 roku wysokość należności gospodarstw domowych wobec monetarnych instytucji finansowych przewyższała poziom z 2015 roku, a największą dynamikę odnotowano w kwietniu 2016 roku. Ponadto wskazano, że największy wzrost nastąpił w obszarze kredytów konsumenckich, to znaczy takich, które przeznaczone są na zaspokojenie bieżących potrzeb gospodarstw domowych. Tak duży wzrost akurat w kwietniu 2016 roku oraz zdecydowana przewaga zobowiązań w 2016 roku w stosunku do 2015 roku, można powiązać z programem pomocy rodzinom „Rodzina 500+”. Program ten oficjalnie wszedł w życie 1 kwietnia 2016 roku. Według założeń, rządowy program ma za zadanie wspierać rodziny w wychowywaniu dzieci przez przyznawanie świadczeń wychowawczych. Pieniądze, które są wypłacane mają pokryć koszty związane z zaspokojeniem potrzeb życiowych oraz ogólnie pojętym wychowywaniem dzieci. Wypłata świadczenia w wysokości 500 zł miesięcznie przysługuje na każde drugie i kolejne dziecko, bez względu na dochody gospodarstwa domowego. Świadczenie na pierwsze dziecko przyznawane jest wtedy, gdy dochód na osobę w gospodarstwie domowym nie przekracza 800 zł, a w przypadku niepełnosprawności dziecka, próg dochodowy został ustalony na poziomie 1200 zł. Świadczenie w postaci dodatkowych 500 zł również wpływało na aktywność ekonomiczną gospodarstw domowych, w tym także związaną z zaciąganiem zobowiązań (dochód rozporządzalny całościowy, jak i ten w przeliczeniu na jedną osobę w gospodarstwie uległ zwiększeniu). W drugim kwartale 2016 roku, aktywa finansowe

Rysunek 4. Aktywa i pasywa gospodarstw domowych w latach 2014-2016 (do 2 kwartału)

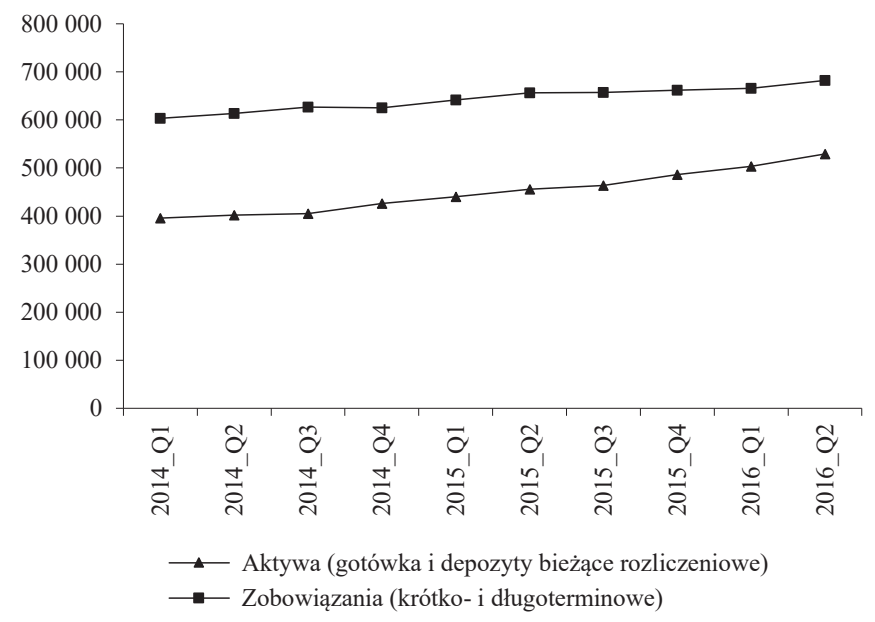

Źródło: opracowanie własne na podstawie danych GUS. 
gospodarstw domowych - gotówka oraz bieżące depozyty rozliczeniowe, były najwyższe od początku badanego okresu (od 2014 r.). Mimo jednak najwyższego poziomu pieniędzy pozostających do dyspozycji gospodarstw domowych, poziom zobowiązań krótko i długoterminowych, również był najwyższy (rys. 4.)

Od początku badanego okresu (od 1 kwartału 2014 r.), przyrost gotówki i depozytów bieżących postępował szybciej niż przyrost zobowiązań. Dodatkowo, od początku stycznia 2014 roku do końca czerwca 2016 roku, zobowiązania zdecydowanie przewyższają aktywa. Najmniejszą różnicę zaobserwowano w drugim kwartale 2016, zaś największą odnotowuje się w trzecim kwartale 2014 roku. W pierwszych trzech kwartałach 2014 roku, wartość aktywów była średnio o 1,53 razy mniejsza niż wartość zobowiązań.

\section{Nadmierne zadłużanie się gospodarstw domowych - przyczyny i skutki}

Z punktu widzenia gospodarstw domowych, finansowe instrumenty dłużne spełniają dwie główne funkcje. $Z$ jednej strony, zaciąganie kredytu pozwala na funkcjonowanie gospodarstw domowych na wyższym poziomie. $Z$ drugiej strony, może być bardzo ważnym źródłem na pokrycie okresowego braku funduszy gospodarstw domowych. Należy zwrócić uwagę na to, że aktualna konsumpcja zależy nie tylko od dochodu bieżącego, ale również przeszłego. Gdy gospodarstwo domowe przez jakiś czas otrzymuje wyższe dochody, struktura spożycia i konsumpcji również jest na wysokim poziomie. Jeśli natomiast dochód ulega zmniejszeniu gospodarstwo domowe nadal chce utrzymać poziom spożycia na dotychczasowym poziomie (tzw. efekt rygla). Zaciąganie pożyczek, kredytów i innych instrumentów pozwala na zachowanie dotychczasowego, wysokiego poziomu konsumpcji, mimo że dochód realny zmniejszył się. Stan taki możliwy jest jednak do utrzymania tylko w krótkim okresie (Duesenberry, 1967).

Cytując noblistę, Miltona Friedmana (No free lunch), stwierdzić można, że zwłaszcza w ekonomii i finansach nie ma nic za darmo. Zatem, w przypadku kredytów zaciąganych przez gospodarstwa domowe, muszą mieć one określony cel, który powinien przynieść jakąś konkretną korzyść temu gospodarstwu domowemu. Korzyści należy określić jako pozafinansowe, dlatego że z założenia, gospodarstwo domowe nie jest podmiotem, który wykonuje działalność, mającą na celu maksymalizację swojego zysku. W przypadku zaciągania kredytów przez gospodarstwa domowe, należy odwołać się do piramidy potrzeb, która określa kolejność zaspokajania potrzeb - od tych, które są najbardziej podstawowe, do potrzeb wyższego rzędu. Obecnie potrzeby kreowane są pod wpływem czynników zewnętrznych oraz wewnętrznych (np. opinie najbliższych, kampanie marketingowe, promocje, moda). W rzeczywistości, konsumpcyjny styl życia może prowadzić do ograniczenia użyteczności dóbr oraz zadowolenia z nich po zakupie, a w konsekwencji zmniejszenia motywacji do spłaty zobowiązania zaciągniętego na zakup danego dobra. W następnym etapie w gospodarstwie domowym powstają coraz to nowe potrzeby, a więc także zwiększają się potrzeby związane z kredytowaniem. Takie zachowanie, prowadzi do zwiększającego się zadłużenia gospodarstw domowych, zwłaszcza w zakresie kredytów długoterminowych, rośnie także konieczność konsolidowania tych zobowiązań (Bogacka-Kisiel, 2012, s. 152-160).

W przypadku, gdy zobowiązanie zaciągane jest na zakup dóbr o wartości trwałej (lub nawet wzrastającej-np. nieruchomość), spłata kredytu w rzeczywistości i w odniesieniu do przyszłości 
jest formą oszczędzania. Pozyskany kapitał obcy stopniowo przekształcany jest w majątek własny. Zaciąganie kredytu stanowi przyrost majątku i bogactwa gospodarstw domowych, w sytuacji kiedy czas użytkowania dobra konsumpcyjnego jest dłuższy od okresu spłaty zobowiązania zaciągniętego na zakup tego dobra.

Na podstawie przeprowadzonej powyżej analizy, autorka zaproponowała następującą listę determinant, powodujących nadmierne zadłużanie się gospodarstw domowych:

1. Konsumpcyjny styl życia.

2. Dodatkowe strumienie i świadczenia pieniężne (które zwiększają zdolność do regulacji i zaciągania zobowiązań).

3. Podatność i reagowanie na bodźce zewnętrzne.

4. Ułatwiony dostęp do instrumentów dłużnych i jednostek, pozwalających na zaciąganie zobowiązań.

5. Brak długofalowych planów finansowych.

Mimo pozytywnego aspektu, zaciąganie kredytów przez gospodarstwa domowe pociąga za sobą głównie negatywne konsekwencje i może prowadzić do nadmiernego zadłużania się tych podmiotów. Dodatkowo, w wielu gospodarstwach domowych może wystąpić problem ze spłatą długów. Ta sytuacja doprowadzić może do zjawiska nazwanego pętlą zadłużenia. Współcześnie dostępność kredytów jest bardzo duża, ale nadmierne zadłużanie się gospodarstw domowych ma związek nie z podażą kredytów, a z decyzjami i zachowaniami finansowymi podejmowanymi przez gospodarstwa domowe. Życie ponad stan, lekkomyślność oraz utrata pracy czy kłopoty rodzinne (czyli oczekiwane i nieoczekiwane zdarzenia), wpływają na równowagę (lub jej brak) finansową oraz na decyzje podejmowane w zakresie zadłużania się (Antonides, van Raaij, 2003, s. 461-462).

\section{Podsumowanie}

Gospodarstwo domowe, jako podmiot udostępniający swoje zasoby, za które otrzymuje zapłatę $\mathrm{w}$ postaci wynagrodzenia, podejmuje wiele decyzji związanych z codziennym funkcjonowaniem. Prócz decyzji o zakupie dóbr i usług, podejmowane są decyzje związane z gospodarowaniem pieniądzem, czyli właśnie decyzje finansowe, do których można zaliczyć decyzje oszczędnościowe, konsumpcyjne, ale także inwestycyjne i kredytowe. Gospodarstwa domowe przejmują ponadto ryzyko związane z podejmowaniem tych decyzji. Decyzje kredytowe związane są przede wszystkim z możliwością regulowania zobowiązań - czyli ze zdolnością kredytową. W nowoczesnej gospodarce podaż kredytowa jest duża, a finansowanie potrzeb gospodarstw domowych uzależnione jest od możliwości korzystania przez nie z finansowych instrumentów dłużnych. Jednak to nie szeroka dostępność kredytów determinuje wysoki poziom zadłużenia gospodarstw domowych. Konsumpcyjny styl życia oraz rosnący dochód rozporządzalny (zwiększany również przez rządowe programy pomocy gospodarstwom domowym), prowadzi do zjawiska nadmiernego zadłużenia oraz pętli zadłużenia. $Z$ roku na rok należności od gospodarstw domowych stale wzrastają, rośnie także udział kredytów na pokrycie potrzeb konsumpcyjnych. 


\section{Literatura}

Antonides, G., van Raaij, W. (2003). Zachowanie konsumenta. Podręcznik akademicki. Warszawa: Wydawnictwo Naukowe PWN.

Bogacka-Kisiel, E. (2012). Finanse osobiste. Zachowania-produkty-strategie. Warszawa: Wydawnictwo Naukowe PWN.

Campbell, J. (2006). Household finance. The Journal of Finance, 61 (4).

Czapiński, J., Panek T. (2015). Diagnoza Społeczna 2015 Warunki i Jakość życia Polaków. Warszawa: Rada Monitoringu Społecznego.

Duesenberry, J. (1967). Income, saving and the theory of consumer behaviour. New York: Oxford University Press.

Drucker, P. (1994). Praktyka zarządzania. Kraków: Akademia Ekonomiczna w Krakowie.

Jajuga, K. (2007). Elementy nauki o finansach. Warszawa: PWE.

Kozielecki, J. (1986). Psychologiczna teoria decyzji. Warszawa: PWN.

Pałaszewska-Reindl, T., Michna, W. (1986). Gospodarstwo domowe - ekonomiczna i organizacyjna baza rodziny polskiej. W: T. Pałaszewska-Reindl (red.), Polskie gospodarstwa domowe: życie codzienne w kryzysie. Warszawa: Instytut Wydawniczy Związków Zawodowych.

Rytelewska, G. (2008). Gospodarstwa domowe. W: B. Pietrzak, Z. Polański, B. Woźniak (red.), System finansowy $w$ Polsce, $t$. II. Warszawa: Wydawnictwo Naukowe PWN.

Samuelson, P., Nordhaus, W. (2005). Ekonomia 1. Warszawa: Wydawnictwo Naukowe PWN.

Samuelson, W., Marks, S. (1998). Ekonomia menedzerska. Warszawa: Wydawnictwo Naukowe PWN.

Światowy, G. (1994). Zachowania konsumenckie. Wrocław: Wydawnictwo Akademii Ekonomicznej im. Oskara Langego.

Świecka, B. (2009). Niewypłacalność gospodarstw domowych. Przyczyny-skutki-przeciwdziałanie. Warszawa: Difin.

Świecka, B., Musiał M. (2014). Zarządzanie finansami gospodarstw domowych w warunkach pogarszającej się sytuacji makroekonomicznej. Zeszyty Naukowe Uniwersytetu Szczecińskiego, 822. Problemy Zarządzania, Finansów i Marketingu, 33 .

Waliszewski, K. (2011). Doradztwo finansowe w Polsce. Warszawa: CeDeWu.

www.nbp.pl.

www.stat.gov.pl.

\section{Cytowanie}

Wiśniewska, A. (2016). Determinanty nadmiernego zadłużania się polskich gospodarstw domowych. Współczesne Finanse. Teoria i Praktyka, 1 (1), 91-100. DOI: 10.18276/wf.2016.1-09. 